Egyptian Journal for Aquaculture

P-ISSN: 2090-7877

E-ISSN: 2636-3984

www.eja.journals.ekb.eg/

Moustafa et al., 2020; 10 (1):01-22

DOI: $10.21608 /$ eja.2020.21286.1012

\title{
Nitrogen and Phosphorus budget for Nile tilapia hatchery
}

\section{Moustafa, Y. T. A. ${ }^{1 *}$; Ahmed A. A. Ali ${ }^{2}$; Safwat A.A. Gomha ${ }^{3}$ and Enas M. Glal ${ }^{1}$.}

1- Limnology department; 2- Fish physiology and hatchery department; 3Aquaculture department, Central Laboratory for Aquaculture Research (CLAR), Agricultural Research Center (ARC).

*ymoustafaonline@yahoo.com

Received: Dec 23, 2019; Accepted: Feb.15, 2020 published: 2020 Vol.10 (1):01-22

\section{Abstract}

Tilapia hatcheries if not well managed, it can cause environmental damage. The present study was designed to quantify the impacts generated by Nile tilapia hatcheries, through applying environmental indicators, which is necessary for tilapia hatcheries sustainable development. Three culture trials, each of 15 days, have been carried out to determine environmental indicators: the nitrogen and phosphorus flux and nutrient mass balance based on inputs from feed and losses in fish harvest, nutrients load in the effluent water, and fish bio-solid wastes (sludge). In each, three cement ponds were assigned to determine the nutrients input and loss for 15 days intervals, fry production cycle. The results showed that every $1 \mathrm{Kg}$ feed of $35 \%$ protein produce $420 \mathrm{~g}$ sludge, of which $262 \mathrm{gm}$ fish excretion. Uneaten feed was found to represent $15.8-20 \%$ of the introduced feed and produce $37.6-43.2 \%$ of sludge. Fish retained at least $25.8 \pm$ $3.91 \%$ and $2.74 \pm 0.37 \%$ of the input feed nitrogen and phosphorus, respectively. While the sludge contained $11.3 \pm$ $0.78 \%$ and $32.62 \pm 14.46$ of the feed nitrogen and phosphorus, respectively. Effluent water contained $43.64 \pm$ $6.45 \%$ and $50.22 \pm 16.63 \%$ of feed nitrogen and phosphorus, respectively, distributed in three main fractions: particulate form; dissolved organic and dissolved inorganic forms. The feed nitrogen recovery in the present study was $80.57 \%$, while the phosphorus recovery reached $85.58 \%$ of the feed phosphorus content. Fry production is discussed in response to the feed protein content and feeding rate.

Keywords: Nile tilapia-hatchery, Oreochromis niloticus, Nitrogen and Phosphorus dynamics, nutrient budgets, fry production. 


\section{INTRODUCTION}

Aquaculture as any aquaculture production activity, if not well managed, it can cause environmental damage (Gorlach-Lira et al., 2013; FAO, 2014). Nutrients load and suspended solids in aquaculture effluent can cause eutrophication (Cho et al., 1991; Ozbay et al., 2014), oxygen depletion (Wu et al., 1994) and algae blooms problems in the surrounding aquatic environments. Moreover, releasing aquaculture effluent of poor quality may have a significant impact on the aquatic organisms in the receiving water bodies (Piedrahita, 2003; Stephens and Farris, 2004). The amount of these pollutants in the effluent depends on a wide range of factors. Their environmental impact can be decreased either by improved farm management, or by physical and/or biological treatment of the effluent. To reduce the nutrient loss; adequately protect surface water quality from the potential negative impact of aquaculture effluent; maintain health and welfare of the fish; achieve high growth and reproduction performance and to increase the efficiency of water use, it is essential to estimate waste production, including the quantity of total solids, phosphorus and nitrogen flux (Westers 1995; Lin and Diana 1996). In this context, several studies documented nitrogen dynamics in aquaculture target systems to ensure and improve the stability and longevity of aquaculture, (Daniels and Boyd, 1989; Acosta-Nassar et al., 1994; Boyd, 1997). However, scarce studies determine nitrogen and phosphorus budget in tilapia hatcheries, within cement ponds, although it is important for tilapia performance and fry production as well as for their hatcheries sustainability. The good management of tilapia hatcheries is mainly grounded on considering the sustainable development factors. Therefore, the input and output must be taken into consideration and the obtained results must be properly evaluated, especially those influence the aquatic environment.

On the other hand, several studies showed that the fish sludge accumulating during fish growing is rich in organic matter, nitrogen and phosphorus (Funge-Smith and Briggs 1994; Hopkins et al., 1994; Jamu and Piedrahita 2001, Boyd et al., 2002). Fish bio-solid wastes (Sludge) accumulation is undesirable as it can negatively impact fish yields due to unpredictable release of toxic elements such as hydrogen sulfides and nitrites. High organic matter deposition is concomitant with a high oxygen demand and lead to oxygen depletion (Boyd and Tucker 1995). Funge-Smith and Briggs (1994) and Lin (2003) reported that although the fish bio-solid wastes are a waste of valuable nutrients, nevertheless, its direct disposal to natural systems possesses an environmental threat. 
A deeper understanding of the interaction between nutrient inputs (feed), nutrient retention (growth) and outputs (soluble and particulate waste) will help address the sustainability of land-based aquaculture production systems (Orellana et al., 2013). Good practice in the management of water resources aims to diminish the cost of water, reducing consumption and maximizing the reuse or recycling of supply water, while returning it to the natural waters with acceptable physicochemical and biological characteristics and, hence, avoiding negative impacts on ecosystems.

So the present study aimed to utilize the environmental indicators as a quantitative tool to evaluate and discuss the nitrogen and phosphorus flux from the hatcheries of Nile tilapia (Oreochromis niloticus Linnaeus, 1758) in cement ponds and subsequently understand nitrogen and phosphorus dynamics in tilapia hatcheries ponds and characterize their environmental impact. So the effective management practices can be recommended to minimize tilapia hatcheries environmental impacts and define the most effective means to treat and reuse the Nile tilapia (Oreochromis niloticus Linnaeus, 1758) hatcheries effluents and biosolid wastes.

\section{MATERIALS and METHODS}

The present study was designed to determine the nitrogen and phosphorus budget, nutrients mass balance and characterize the effluent and sludge of Nile tilapia brood-stock's cement ponds, in the Central Laboratory for Aquaculture Research (CLAR) hatchery, Abbassa, AbuoHammad, Shrakia governor.

During three successive culture trials on $23^{\text {rd }}$ May 2017 through

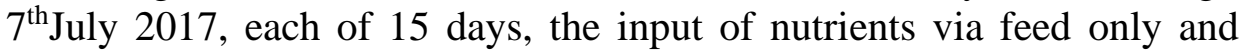
nutrients loss in fish biomass, nutrients settled in sludge, nutrients load in the effluents and the nutrients mass balance, are the environmental indicators that have been determined in this study.

To achieve that goal three cement ponds with dimension of $2.80 \times$ $8.1 \times 1.5 \mathrm{~m}$ were assigned for the environmental indicators determination in each culture trial and filled with water at $50 \mathrm{~cm}$ high, with a working volume of $11340 \mathrm{~L}$, and stocked with 60 Nile tilapia fish with an average weight of $160 \pm 2 \mathrm{gm}$, at sex ratio of 3 female: 1 male. The daily feeding rate was adjusted at $1.2 \%$ of the total fish biomass, introduced twice daily at 9:00 and 15:00 using feed of $5.53 \%$ nitrogen (35\% crude protein) and $0.191 \%$ phosphorus contents. 
In order to a chive the objectives of the study, the amount of water in the ponds were used during the study period without replacement except for compensation for the loss of evaporation.

\section{Nutrient budgets and mass balance}

The considered nutrient gains source was feed while considered nutrient losses were the gain weight of harvested fish, drainage water and collected tanks sediment (sludge).

To estimate total nutrient gains from feed, feed proximate analyses were made for total nitrogen as well as total phosphorus contents.

To estimate nutrient contribution of affluent water, water samples were collected from the inlet pipe during ponds filling and evaporation compensation and their nitrogen and phosphorus contents were determined. To calculate the nutrient contribution from feed in the ponds water (Nutrients Mass Balance, NMB), the nutrient load in affluent water $\left(\mathrm{L}_{\mathrm{A}}\right)$ was subtracted from the effluent nutrient load $\left(\mathrm{L}_{\mathrm{E}}\right)$ at the end of each culture trials (15days), according to the following Equation ((Boyd and Queiroz, 2001; Boyd et al., 2007; Osti et al., 2018) :

$\mathrm{NMB}=\mathrm{L}_{\mathrm{E}}-\mathrm{L}_{\mathrm{A}}$

Where: $\mathrm{NMB}=$ nutrients mass balance loads of $(\mathrm{TP}$ and $\mathrm{TN})$

$\mathrm{L}_{\mathrm{E}}=$ the considered variable load in the effluent of the ponds

$\mathrm{L}_{\mathrm{A}}=$ the considered variable load in the affluent of the ponds

Also, different forms of nitrogen and phosphorus in affluent (at the beginning of each culture trial) and effluent water (at the end of each culture trail) were measured to determine the feed contribution in nitrogen and phosphorus forms in water.

For considered losses in sludge, sediments from each pond were collected during fry harvest and its TN and TP were determined. Final fish samples, at the end of spawning season, were collected and their TN and TP were determined and multiply in weight gain at the end of each culture trial, to measure $\mathrm{N}$ and $\mathrm{P}$ loose in fish biomass.

\section{Sludge of different sources determination:}

Affluent water: The volume of water added to ponds was estimated by monitoring water levels in each fish pond. Gradual signs (100 cm high) were marked on the cement ponds walls to monitor changes in ponds water depth and volume. The total suspended solids were determined according to APHA (1998). The amount of solids was calculated (11.7 $\mathrm{mg} / \mathrm{l}$ which means $132 \mathrm{~g}$ of sediment/ tank of $11340 \mathrm{~L}$ per 15 days). 
Feed: Commercial feed (35\% crude protein) was used throughout the experiment and the quantity of feed inputs into the fish ponds were introduce twice daily (9:00 and 15:00) and recorded daily then quantified at the end of the each culture trial (15 days) and the feed contribution to sediment accumulation was estimated based on assumption that every $1 \mathrm{Kg}$ feed produce about $412 \mathrm{gm}$ sediment (Muendo et al., 2014), and 15\% of the offered feed is not eaten (Boyd 1995; Boyd and Tucker, 1995).

\section{Chemical analysis:}

Total nitrogen in sludge, fish and feed was analyzed by the Kjeldahl method (AOAC 1990). The total phosphorus content in sludge; fish and feed was determined by using dry ash method (Tavares and Boyd, 2003) for digestion then phosphorus was colorimetrically estimated using the vanadomolybdate method (APHA, 1985).

Affluent and effluent water samples were collected at the beginning and ending of each culture trial, respectively, from each pond for analysis and determination of : total solids (TSS), $\mathrm{NH}_{4} ; \mathrm{NO}_{2} ; \mathrm{NO}_{3}$, total nitrogen of sample before filtration (TN); Total dissolved nitrogen(TDN) of sample after filtration; total phosphorus of sample before filtration (TP); total dissolved phosphorus (TDP) of sample after filtration and orthophosphate (OP) according to the analytical methods of AOAC (1990).

The total nitrogen and total phosphorus were determined according to (Gross and Boyd 1998) and (Boyd 1979) for the nitrogen determination and ascorbic acid method (Boyd and Tucker 1992) for the phosphorus.

Particulate nitrogen (Part.N); particulate phosphorus (Part. P); dissolved organic nitrogen (DON); and dissolved organic phosphate (DOP) were calculated.

\section{Calculations:}

Total nutrient (Nitrogen / Phosphorus) Input per pond $\left(\mathrm{TN}_{\mathrm{I}}\right)=$ Total amount of applied feed $(\mathrm{kg}) \times$ average of dry matter fraction $\times$ average of nutrient (nitrogen/Phosphorus) content in dry feed $(\mathrm{Kg})$ by $\mathrm{Kg}$ of feed Nutrient loss in fish biomass was calculated as following equation $\mathrm{N}_{\mathrm{B}}=\mathrm{P} \times \mathrm{DM} \times \mathrm{N}_{\mathrm{DM}}$

Where: NB = converted nutrient in fish biomass $(\mathrm{kg}$ of TP or TN), $\mathrm{P}=$ fish gain weight $(\mathrm{kg})$ at the end of each culture trial, $\mathrm{DM}=$ amount of dry matter by kilogram of fish $(\mathrm{kg}), \mathrm{N}_{\mathrm{DM}}=$ amount of nutrient $(\mathrm{TP}$ or $\mathrm{TN})$ by 
kilogram of dry matter of fish (kg) (Boyd and Queiroz, 2001; Boyd et al., 2007).

According to Thoman et al., (2001) the following equations have been used to determine different fractions of nutrients in water.

Particulate nitrogen $=$ total nitrogen $(\mathrm{TN})$ before sample filtration $-\mathrm{TDN}$ after sample filtration

Dissolved inorganic nitrogen $(\mathrm{DIN})=\mathrm{NH}_{4}+\mathrm{NO}_{2}+\mathrm{NO}_{3} \mathrm{mg} / \mathrm{L}$

Dissolved organic nitrogen $(\mathrm{DON})=\mathrm{TDN}$ after sample filtration $-\mathrm{DIN}$

Particulate phosphorus $=$ total phosphorus $(\mathrm{TP})$ before sample filtration TDP after sample filtration

Dissolved organic phosphorus $(\mathrm{DOP})=$ TDP after sample filtration Orthophosphate

\%Total nutrients (Nitrogen/Phosphorus) Recovery (TNR; per tank) $=\%$ Nutrient $(\mathrm{N} / \mathrm{P})$ Fish $)+\%$ Nutrient in sludge $+\%$ inorganic fraction of nutrient $(\mathrm{DIN} / \mathrm{OP})$ in water $+\%$ organic Nutrient $(\mathrm{DON} / \mathrm{DOP})$ in water + particulate nutrients (Part.N/Part. P) in water.

\section{RESULTS and DISCUSSION}

\section{Fish growth:}

At the beginning of the experiment, $23^{\text {rd }}$ May of 2017, the average weight of fish in the ponds was $160 \pm 2 \mathrm{~g}$. At the end of the experiment, $7^{\text {th }}$ July of 2017, the average fish weight was $173.5 \pm 3.5 \mathrm{~g}$. The feed intake was of $5.55 \mathrm{~kg} / 45$ days and the feeding rate was adjusted at $1.2 \%$ of the total fish biomass.

\section{TSS:}

TSS in affluent water was found to be $11.7 \mathrm{mg} / \mathrm{liter}$ and produced about132 gm sediment/pond of $11340 \mathrm{~L}$ working volume, which represents about12.8-15.2\% of the total produced sludge at the end of the culture trial. According to the literatures, every $\mathrm{Kg}$ feed produces about 412 gm sludge of which less than $10 \%$ attributed to the affluent water (Muendo et al., 2014).

The TSS as a result of feeding was determined before a meal and after 3 and $6 \mathrm{~h}$ of the meal, in the present work. Uneaten feed was found to represent $15.8-20 \%$ of the introduced feed and produce $37.6-43.2 \%$ of sludge result of feed and the rest of feed's sludge was a result of fish excretion. So, $1 \mathrm{Kg}$ of the applied feed produced $262 \mathrm{gm}$ fish solid excretion and about $420 \mathrm{gm}$ sludge/1kg feed. Similarly, Boyd (1995); Boyd and Tucker (1995) estimated the uneaten feed to be $15 \%$ of the 
introduced feed. Also, in the present study, the estimated fish excretion $(31.1-32.7 \%$ of the ingested feed) is closer to the $30 \%$ of the ingested feed reported by Porter et al., (1987). In general, in fish that masticate pellets, such as tilapia or tambaqui (Colossoma macropomum (Cuvier 1818)), uneaten feed was found to range between $10 \%$ and $30 \%$ of the applied feed (Van Der Meer et al. 1997). While, species that swallow the pellet such as European eel or African catfish (Clarias gariepinus (Burchell 1822)), have feed losses varies between 1 and $10 \%$ (Heinsbroek et al. 1989).Our results are also similar to those reported by Summerfelt et al., (2001) who calculated that every kilogram of fed feed emits $0.43 \mathrm{~kg}$ of suspended solids, additional $9 \%$ suspended solids of feed emerge from activity of heterotrophic organisms and another $0.09 \%$ - due to activity of nitrification bacteria. Mongirdas et al., (2017) reported that it is unreal to expect less than $200 \mathrm{~g}$ of sediment in real growing conditions, and values higher than $450 \mathrm{~g}$ does not appear as well, because that would suggest uneconomical use of feed and would extremely increase the first cost of fish production.

Fish bio-solid wastes (Sludge) accumulation is undesirable as it can negatively impact fish yields due to unpredictable release of toxic elements such as hydrogen sulfides and nitrites. High organic matter deposition is concomitant with a high oxygen demand and lead to oxygen depletion (Boyd and Tucker 1995). Funge-Smith (1994); Smith (1996) and Lin (2003) reported that although the fish bio-solid wastes are a waste of valuable nutrients, nevertheless, its disposal to natural systems possesses an environmental threat. Therefore it is necessary to search for a suitable treatment before using it, i.e., vermicomposting (Kouba et al., 2018).

\section{Nitrogen budget:}

The affluent water contribution in nitrogen and phosphorus budget was calculated and deducted from different fractions of nitrogen and phosphorus data, so the feed became the only measured nutrients source as shown in tables of nitrogen and phosphorus (Tables 1\&2).

The data of the nitrogen budget is shown in Table (1), nitrogen added in feed; nitrogen retained in fish; nitrogen lost in sludge as well as different nitrogen fractions lost in drainage water. Based on the proposed indicators by Boyd and Queiroz (2001) and Boyd et al. (2007) for nutrients, fish retained at least $25.8 \%$ of the input feed nitrogen as the results showed (Table 1). The present study results are superior over the results reported by Avnimelech (1999) who found only $23 \%$ of the feed 
protein was recovered by the hybrids tilapia fish stocked in $50 \mathrm{~m}^{2}$ ponds at a density of 80 fish $/ \mathrm{m}^{2}$ and fed $30 \%$ protein diet. Similar results registered by Boyd et al. (2007) who estimated that $23 \%$ of TN introduced in the fishponds as feed were converted in tilapia biomass. Far lower retention percent reported by Lin et al., (1996) $15.45-20.04 \% \mathrm{~N}$ from the total inputs, for tilapia fish in fertilized earthen ponds. The present work results are in consistence with Avnimelech, (2006) and Osti et al., (2018) who found that $26 \%-30 \%$ of the offered feed's nutrients are assimilated for fish biomass growing. Also our results are consistent with Boyd, (1985); Muthuwani and Lin, (1996) who reported that fish in a pond assimilate only about $25 \%$ of the nitrogen added in the feed and the rest is excreted as $\mathrm{NH}_{4}$ or as organic $\mathrm{N}$ in feces or feed residue. Nevertheless, Wang et al. (2012) have found 38\% of TN which entered the system in the form of feed is reversed into fish biomass and the remaining $62 \%$ were released to the environment.

Several studies showed that the fish sludge accumulating during fish growing is rich in organic matter, nitrogen and phosphorus (Funge-Smith and Briggs 1994; Hopkins et al., 1994; Jamu and Piedrahita 2001, Boyd et al., 2002). However, in the present study we found that sludge contain less nutrient than water, this can be attributed to the very short period of the fry collection, every 15 days, compared to the fish growing season, that may last for 4 months, that did not provide enough time for solid settlement. Muendo et al. (2005) reported that in tilapia ponds in the Nile delta, never drained, the concentration of nitrogen in the seepage water is 6.5 times higher than in water $2-10 \mathrm{~cm}$ above the sediment. As the results showed (Table 1), the sludge contained $11.3 \pm 0.78 \%$ of the feed nitrogen, as a total of fish excretion and uneaten feed settled at the tank bottom. Nitrogen content in fish feces was reported to vary from 10 to $40 \%$ depending on nitrogen content of fish feed and fish species (Lupatsch and Kissil, 1998; Schneider et al., 2004; van Rijn, 2013).

Water Total nitrogen in the present study was $4 \pm 0.68 \mathrm{mg} / \mathrm{L}$ that represented $43.64 \pm 6.45 \%$ of the feed nitrogen content distributed in three main fractions: particulate $\mathrm{N}$; dissolved organic $\mathrm{N}$ and dissolved inorganic N. Osti et al., (2018) and Boyd and Queiroz (2001) reported that $16 \% \mathrm{TN}$ which entered the system in the form of feed were exported by effluent.

Water particulate nitrogen represented $13.29 \pm 7.27 \%$ of feed nitrogen, while total dissolved nitrogen was $30.35 \pm 8.68 \%$ of feed nitrogen. Dissolved inorganic nitrogen was determined to be $10.78 \%$ of feed nitrogen, while dissolved organic nitrogen was $19.57 \pm 4.31 \%$ of feed 
nitrogen. Similarly, Cripps and Bergheim (2000) reported that particulate wastes commonly contain $7-32 \%$ of the total nitrogen (TN) and the remainder is in the dissolved fraction in wastewater. Mongirdas et al., (2017) reported that nitrogen from protein, used up during fish vital processes is emitted through gill $-60-90 \%$ - as ammonia and 9-27\% as urea. However, dissolved organic nitrogen (DON) in the present study was higher than dissolved inorganic nitrogen (DIN) and that can be attributed for two reasons: organic form of nitrogen as well as phosphorus needs time (i.e. more than 4 weeks, Summerfelt and Vinci 2003) for mineralization through the microbial activity and the inorganic nitrogen fraction is consumed by the phytoplankton over short time scale. Muendo et al., (2014) also reported that the organic forms of nutrients will become available after some time through microbial activity. On the other hand, Thoman (2001) determined that nitrogen loss via denitrification process reach $9-21 \%$ of the total nitrogen input in recirculating systems. While, Daniels and Boyd (1989) estimated that $50 \%$ of the nitrogen entering via the feed was lost through the combined effects of denitrification and ammonia volatilization in polyethylenelined, brackishwater ponds. Acosta-Nassar et al. (1994) estimated that only $1 \%$ of the total nitrogen was lost through denitrification in a semiintensive freshwater fish culture pond. The feed nitrogen recovery in the present study was $80.57 \%$. Thoman et al., (2001) reported average total nitrogen recovery ranged from 91.4 to $79.3 \%$.

The unaccounted part of nitrogen loss can be attributed to ammonia volatilization and denitrification processes; however we could not measure these processes due to a lack of facilities. Daniels and Boyd (1989) estimated that $50 \%$ of the nitrogen entering via the feed was lost through the combined effects of denitrification and ammonia volatilization in polyethylene-lined, brackishwater ponds. Lin et al., (1996) reported the unaccounted loss of $\mathrm{N}$ between $70.66-78.01 \%$ of the total inputs, and the losses of $\mathrm{N}$ in discharged water ranged from 7.19$10.81 \%$ of the total inputs, and attributed the large amount of unaccounted nitrogen to losses through denitrification process in the sediment. Nevertheless, ammonia loss by volatilization is considered to be insignificant in aquaculture systems those with low concentration of $\mathrm{NH}_{3}$, where ammonia volatilization rate correlates with $\mathrm{NH}_{3}$ concentration (Zimmo et al., 2004). 
Table (1): Nitrogen budget, input and excreted fractions in Nile tilapia brood stock concrete ponds.

\begin{tabular}{|c|c|c|c|c|c|c|c|c|c|c|}
\hline \multirow{2}{*}{$\begin{array}{l}\text { Parameter } \\
\text { Unit }\end{array}$} & \multirow{2}{*}{$\begin{array}{ll}\text { Feed } & \mathrm{N} \\
\text { input }\end{array}$} & \multirow{2}{*}{$\begin{array}{l}\text { Nitrogen } \\
\text { retained } \\
\text { in Fish }\end{array}$} & \multirow{2}{*}{$\begin{array}{l}\text { Nitroge } \\
\mathrm{n} \quad \text { in } \\
\text { sludge }\end{array}$} & \multicolumn{7}{|c|}{ Water Nitrogen } \\
\hline & & & & $\mathrm{TN}$ & TDN & Part. N & DO N & $\mathrm{NH}_{4}$ & $\mathrm{NO}_{2}$ & $\mathrm{NO}_{3}$ \\
\hline$(\mathrm{mg} / \mathrm{L})$ & & & & $\begin{array}{l}4.00 \pm \\
0.68\end{array}$ & $\begin{array}{l}2.76 \pm \\
0.77\end{array}$ & $\begin{array}{l}1.24 \pm \\
0.73\end{array}$ & $\begin{array}{l}1.78 \pm \\
0.39\end{array}$ & $\begin{array}{l}0.20 \\
\pm 0.1\end{array}$ & $\begin{array}{l}0.13 \pm \\
0.06\end{array}$ & $\begin{array}{ll}0.65 & \pm \\
0.39 & \end{array}$ \\
\hline g/pond & $\begin{array}{l}103.60 \pm \\
4.73\end{array}$ & $\begin{array}{l}26.59 \pm \\
2.64\end{array}$ & $\begin{array}{l}11.53 \pm \\
1.18\end{array}$ & $\begin{array}{l}45.34 \\
\pm 7.73\end{array}$ & $\begin{array}{l}31.32 \\
\pm 8.7\end{array}$ & $\begin{array}{l}14.02 \\
\pm 8.27\end{array}$ & $\begin{array}{l}20.24 \\
\pm 4.37\end{array}$ & $\begin{array}{l}2.26 \\
\pm \\
1.16\end{array}$ & $\begin{array}{l}1.44 \quad \pm \\
0.73\end{array}$ & $\begin{array}{l}7.39 \quad \pm \\
4.44\end{array}$ \\
\hline $\begin{array}{l}\% \text { of feed } \\
\mathrm{N}\end{array}$ & & $\begin{array}{l}25.8 \quad \pm \\
3.91\end{array}$ & $\begin{array}{l}11.13 \pm \\
0.78\end{array}$ & $\begin{array}{l}43.64 \\
\pm 6.45\end{array}$ & $\begin{array}{l}30.35 \\
\pm 8.68\end{array}$ & $\begin{array}{l}13.29 \\
\pm 7.27\end{array}$ & $\begin{array}{l}19.57 \\
\pm 4.31\end{array}$ & $\begin{array}{l}2.20 \\
\pm \\
1.16\end{array}$ & $\begin{array}{l}1.37 \pm \\
0.65\end{array}$ & $\begin{array}{l}7.21 \\
4.34\end{array}$ \\
\hline
\end{tabular}

$\mathrm{TN}=$ Total nitrogen; TDN = Total dissolved nitrogen, Part.N = particulate nitrogen; DON = Dissolved organic nitrogen. Each value is an average of 9 replicate \pm standard deviation. 


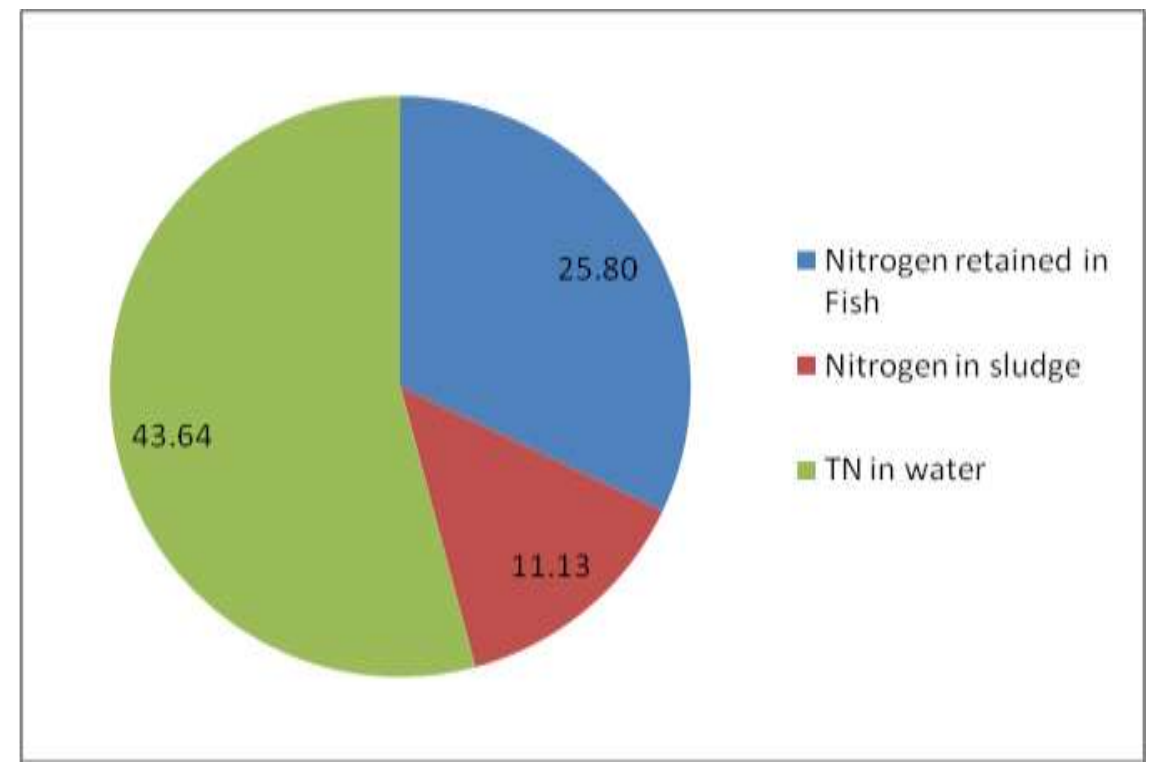

Fig (1) Nitrogen budget in Nile tilapia brood stock concrete ponds

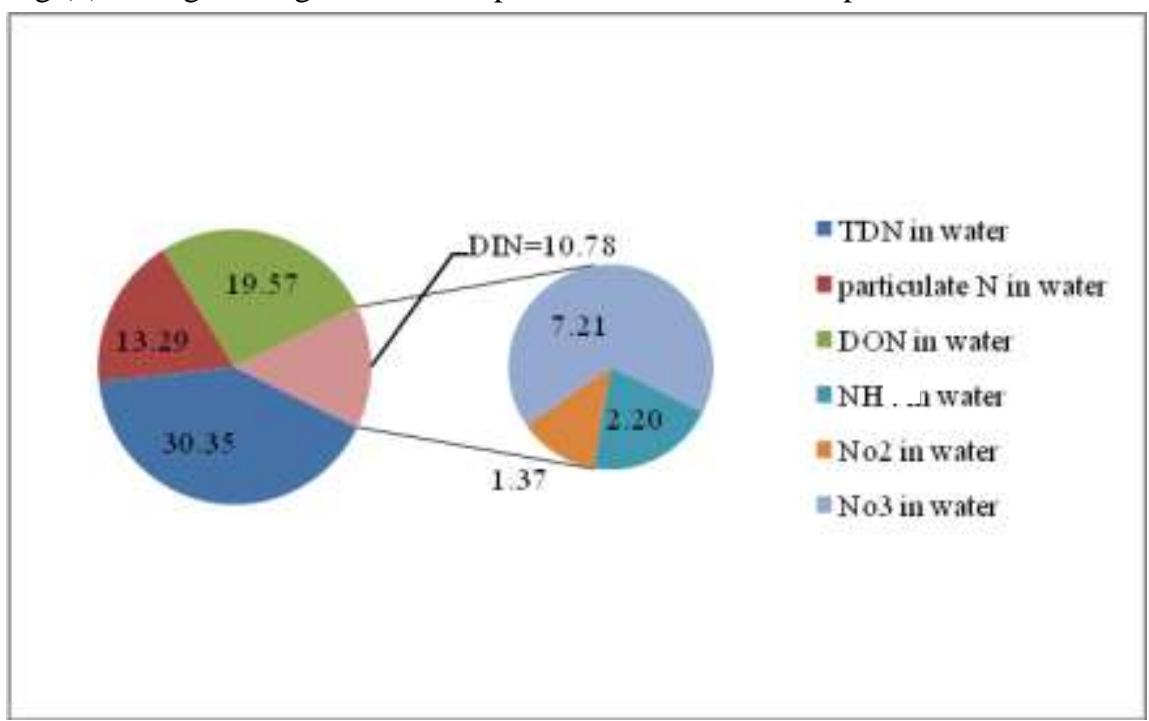

Fig (2) Nitrogen fractions in water in Nile tilapia brood stock concrete tanks, TDN= total dissolved nitrogen, $\mathrm{DON}=$ dissolved organic nitrogen, $\mathrm{DIN}=$ dissolved inorganic nitrogen.

\section{Phosphorus budget:}

In freshwater bodies, phosphorus is the main limiting factor for development of flora. Unused feed phosphorus in aquaculture, make its way to environment and encourages eutrophication (Mongirdas et al., 
2017). In the present study results showed that fish retained at least 2.74 $\pm 0.37 \%$ of the feed phosphorus content. The assimilation of phosphorus, for different species of fish, depends on the composition of feed. Beveridge (1984) reported that Tilapia assimilates only $65 \%$ of phosphorus in fishmeal compared to salmon, and carp practically does not assimilate it at all - it requires phosphorus from plant-based ingredients. A higher percent $10.02-15.10 \% \mathrm{P}$ from the total $\mathrm{P}$ inputs was reported to be retained in tilapia fish by Lin et al., (1996) in fertilized earthen ponds. Wang et al. (2012), have found that 30\% TP which entered the system in the form of feed were reversed into fish biomass.

The un-dissolved fraction of phosphorus, in the present study, was determined to be more than $37 \%$ of feed phosphorus $(32.62 \pm 14.46 \%$ in sludge and $5.35 \pm 3.86 \%$ of the total feed phosphorus as particulate $\mathrm{P}$ in water). Cripps and Bergheim, (2000) also reported that the main part of feed phosphorus, $30 \%-84 \%$ of the total phosphorus (TP), is in undissolved fraction, i.e. is not assimilated. At a feed conversion ratio of $1.0 \mathrm{~kg}$ feed $\mathrm{kg}^{-1}$ gain, the estimated discharges from juvenile salmonids in terms of $\mathrm{g}(\mathrm{P}) \mathrm{kg}^{-1}$ fish gain $7.5 \mathrm{~g} \mathrm{P} \quad(80 \%-90 \%$ solid-bound) (Cripps, Bergheim, 2000). Foy and Rosell (1991); Kelly et al., (1994) showed that the proportion of nutrients in the particulate fraction increased with temperature. Shrestha and Lin, (1996) reported that sedimentation is generally considered a main mechanism for P loss in ponds because mud are known to have a strong affinity for phosphorus. Phosphorus and organic matter are released largely as particulate matter (Piedrahita, 2003), which is matching with the present work founds, more than $37 \%$ of feed $\mathrm{P}$ in un-dissolved form. In general several studies have reported that in fish ponds with age of 1-30 years the total phosphorus concentrations in sediment ranging from 0.334 to 1.73 $\mathrm{g} / \mathrm{kg}$ while the available phosphorus concentrations ranged 0.005 to $0.022 \mathrm{~g} / \mathrm{kg}$ (Wahab et al., 1984, , Ming-Kui and Li-ping 2006, Wudtisin and Boyd 2006).

The water in tilapia brood-stock tanks contained $50.22 \pm 16.63 \%$ of the feed phosphorus content distributed in three main fractions: particulate phosphorus $(5.35 \pm 3.86 \%$ of feed phosphorus content); dissolved organic phosphorus (16.47 $\pm 7.69 \%$ of the feed phosphorus content) and dissolved inorganic phosphorus $(28.41 \pm 10.65 \%$ of the feed phosphorus content). The phosphorus recovery in the present study reached $85.58 \%$ of the feed phosphorus content. Lin et al., (1996) reported the losses of $\mathrm{P}$ in discharged water ranged from $2.00-3.84 \%$ of the total inputs, and the unaccounted loss of $\mathrm{P}$ between $81.88-87.25 \%$ of the total $\mathrm{P}$ inputs. 
Muendo et al. (2005) reported that in tilapia ponds in the Nile delta, never drained, the concentration of phosphorus in the seepage water is 21 times more concentrated than pond water. Osti et al., (2018) and Boyd and Queiroz (2001) reported that $11 \% \mathrm{TP}$ which entered the system in the form of feed were exported by effluent. However, Wang et al. (2012), have found that $70 \%$ TP which entered the system in the form of feed were released to the environment, which is matching with the present study founds, where more than $82 \%$ of the total $\mathrm{P}$ input was exported to the environment in dissolved form in water and settled form in sludge.

Table (2): Phosphorus budget, input and excreted fractions in Nile tilapia brood stock concrete ponds.

\begin{tabular}{|c|c|c|c|c|c|c|c|c|}
\hline Parameter & \multirow{2}{*}{$\begin{array}{l}\text { Feed } \\
\mathrm{P} \\
\text { input }\end{array}$} & \multirow{2}{*}{$\begin{array}{l}\text { Phosphorus } \\
\text { retained in } \\
\text { Fish }\end{array}$} & \multirow{2}{*}{$\begin{array}{l}\text { Phosphorus } \\
\text { in sludge }\end{array}$} & \multicolumn{5}{|c|}{ Water Phosphorus } \\
\hline Unit & & & & $\mathrm{TP}$ & $\mathrm{TDP}$ & $\begin{array}{l}\text { Part. } \\
\text { P }\end{array}$ & DOP & OP \\
\hline$(\mathrm{mg} / \mathrm{L})$ & & & & $\begin{array}{l}0.16 \pm \\
0.05\end{array}$ & $\begin{array}{l}0.14 \\
\pm \\
0.05\end{array}$ & $\begin{array}{l}0.02 \\
\pm \\
0.01 \\
\end{array}$ & $\begin{array}{l}0.05 \\
\pm \\
0.02\end{array}$ & $\begin{array}{l}0.09 \pm \\
0.03\end{array}$ \\
\hline $\mathrm{g} /$ pond & $\begin{array}{l}3.53 \\
\pm 0.16\end{array}$ & $\begin{array}{l}0.10 \\
\pm 0.01\end{array}$ & $\begin{array}{l}1.16 \\
\pm 0.51\end{array}$ & $\begin{array}{l}1.77 \\
\pm 0.56\end{array}$ & $\begin{array}{l}1.58 \\
\pm 0.53\end{array}$ & $\begin{array}{l}0.18 \\
\pm 0.13\end{array}$ & $\begin{array}{l}0.58 \\
\pm 0.27\end{array}$ & $\begin{array}{l}1.00 \\
\pm 0.38\end{array}$ \\
\hline $\begin{array}{l}\% \text { of feed } \\
\mathrm{P}\end{array}$ & & $\begin{array}{l}2.74 \\
\pm 0.37\end{array}$ & $\begin{array}{l}32.62 \\
\pm 14.46\end{array}$ & $\begin{array}{l}50.22 \\
\pm 16.63\end{array}$ & $\begin{array}{l}44.87 \\
\pm 15.2\end{array}$ & $\begin{array}{l}5.35 \\
\pm 3.86\end{array}$ & $\begin{array}{l}16.47 \\
\pm 7.69\end{array}$ & $\begin{array}{l}28.41 \\
\pm 10.65\end{array}$ \\
\hline
\end{tabular}

$\mathrm{TP}=$ total phosphorus; $\mathrm{TDP}=$ total dissolved phosphorus; $\mathrm{Part} . \mathrm{P}=$ particulate phosphorus; $\mathrm{DOP}=$ dissolved organic phosphorus; $\mathrm{OP}=$ ortho phosphste. Each value is an average of 9 replicate \pm standard deviation. 


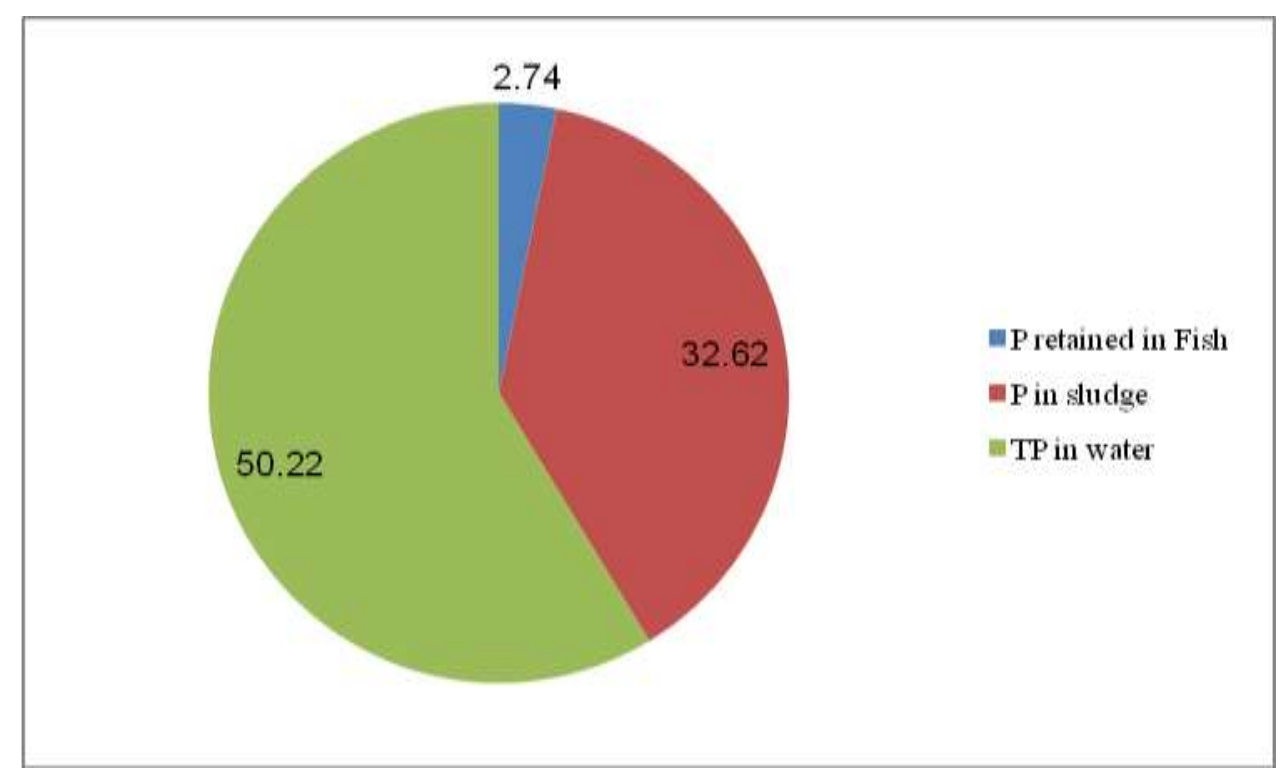

Fig (3) Phosphorus budget in Nile tilapia brood stock concrete ponds

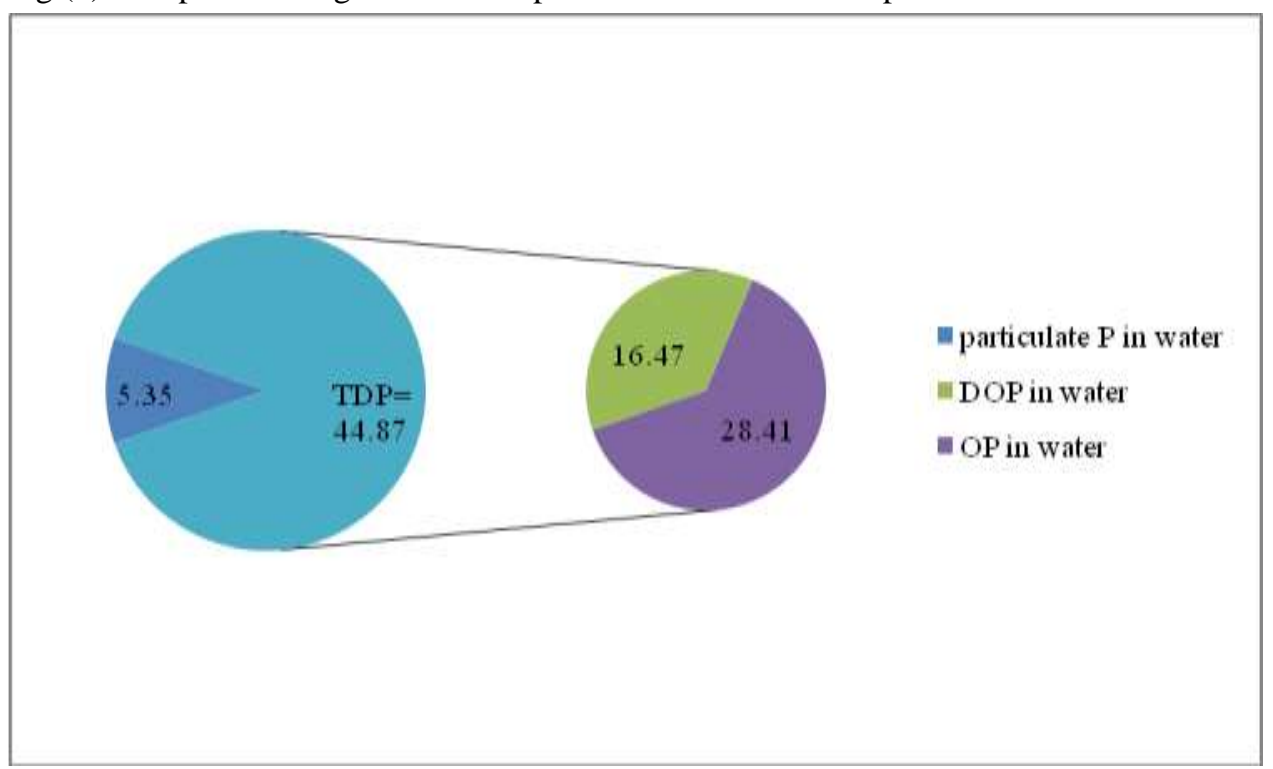

Fig (4) Phosphorus frictions in waster in Nile tilapia brood stock concrete tanks, TDP = total dissolved phosphorus, $\mathrm{DOP}=$ dissolved organic phosphorus, $\mathrm{OP}=$ ortho-phosphate.

Organic phosphorus fraction was found, in the present work, to represent about $16.47 \pm 7.69 \%$ of the total phosphorus input as feed. Similarly, several studies reported organic phosphorus to form 23-60\% of the total phosphorus (Rath 2000, Boyd et al., 2006, Ming-Kui and Li-ping 2006). 
Table (3) fry production in brood-stock cement tanks of Tilapia Hatchery

\begin{tabular}{|c|c|c|c|c|c|c|}
\hline \multirow[t]{2}{*}{ Trials } & \multicolumn{2}{|l|}{$\mathrm{R} 1$} & \multicolumn{2}{|l|}{$\mathrm{R} 2$} & \multicolumn{2}{|l|}{ R3 } \\
\hline & $\begin{array}{l}\text { No.fry/fem } \\
\text { ale }\end{array}$ & $\begin{array}{l}\text { No.fry/pon } \\
\text { d }\end{array}$ & $\begin{array}{l}\text { No.fry/fem } \\
\text { ale }\end{array}$ & $\begin{array}{l}\text { No.fry/pon } \\
\text { d }\end{array}$ & $\begin{array}{l}\text { No.fry/fem } \\
\text { ale }\end{array}$ & $\begin{array}{l}\text { No.fry/po } \\
\text { nd }\end{array}$ \\
\hline Trial 1 & 390 & 17550 & 410 & 18450 & 400 & 18000 \\
\hline Trial 2 & 405 & 18225 & 420 & 18900 & 430 & 19350 \\
\hline Trial 3 & 440 & 19800 & 455 & 20475 & 435 & 19575 \\
\hline $\begin{array}{l}\text { Aver } \pm \\
\text { SD }\end{array}$ & $\begin{array}{c}411.7 \pm \\
25.7\end{array}$ & $\begin{array}{c}18525 \pm \\
1154.6\end{array}$ & $\begin{array}{c}428.3 \pm \\
23.6\end{array}$ & $\begin{array}{c}19275 \pm \\
1063.3\end{array}$ & $\begin{array}{c}421.7 \pm \\
18.9\end{array}$ & $\begin{array}{c}18975 \pm 85 \\
1.8\end{array}$ \\
\hline
\end{tabular}

In the present study the applied feed contains 5.53\% $\mathrm{N}$ (35\% protein). According to Hassouna et al., (2002) who stated that the reproductive performance significantly improve by increasing crude protein $(\mathrm{CP})$ level in the commercial diets and that from the economic and production points of view, the $35 \%$ diet seems more suitable and efficient than other tested higher or lower levels .

In the present work the feeding ration was calculated to be $1.2 \%$ of the total fish biomass. Also, Santiago, (1985) better reproduction activity was reached when Tilapia breeders were fed with pelleted supplemental diets containing 20 or $40 \%$ crude protein at a daily feeding rate of $1 \%$ of fish biomass for 24 weeks in cages and tanks. However, Abou-Zied and Ali (2007) found that brood-stock feeding rate at low (less than $1 \%$ of the total fish biomass) level was more effective in increasing fry production than higher levels. This may suggest that at lower feeding rate the uneaten feed would be less than that has been determined in the present study.

\section{CONCLUSIONS}

The present work is based on monitoring of changes in the distribution of nitrogen $\mathrm{N}$ and phosphorus $\mathrm{P}$ in water, suspended matter and fish in a pond experiment, where applied feed was the only considered nutrient source. The objective of this work were to get data on the nutrients fate in the tilapia hatchery ponds system, and understanding the nitrogen and phosphorus fractions dynamics in order to define the most suitable and effective treatment practice for the effluent and sludge before reuse them. In the present study, at a feeding rate of $1.2 \%$ of the total fish biomass, it was found that the average net uptake of $\mathrm{N}$ and $\mathrm{P} 25.8 \pm 3.91 \%$ and 2.74 
$\pm 0.37 \%$ of the input feed $\mathrm{N}$ and $\mathrm{P}$ contents. This is a significant contribution to fish feeding in such systems. On the other hand the uneaten feed was found to represent $15.8-20 \%$ of the introduced feed and produce 37.6 - $43.2 \%$ of sludge, this percent may be reduced by reducing the feeding rate, although the uneaten feed percent is responding to the fish species too.

The net uptake (fish retention), though an important parameter, is just a part of the processes involved. Part of the nitrogen and phosphorus taken up by fish is excreted. The present study elucidated that while the sludge contained $11.3 \pm 0.78 \%$ and $32.62 \pm 14.46$ of the feed nitrogen and phosphorus, respectively. Effluent water contained $43.64 \pm 6.45 \%$ and $50.22 \pm 16.63 \%$ of feed nitrogen and phosphorus, respectively, distributed in three main fractions: particulate form; dissolved organic and dissolved inorganic forms. This information is of utmost importance to plan the wastewater treatment in order to reduce the water use, as well as in deciding how to utilize the produced sludge efficiently. Therefore the present study's results are of great economic and environment gains for aquaculture sustainable development.

The monitoring nutrients changes in the aquatic environment (dissolved and particulate) approach achieved a nitrogen recovery (80. 57\%) and phosphorus recovery $(85.58 \%)$. However, we did not consider other processes that may affect the nitrogen balance, i.e. nitrification and dentrification. A complicated isotopic technique of tagged nitrogen ${ }^{15} \mathrm{~N}$ is needed for more details.

\section{REFERENCES}

Abou-Zied R.M. and Ali A.A.A., 2007. Evaluation of Nile tilapia commercial hatcheries systems in fayoum governorate. Egypt J.Aquat. Bio.\&Fish., Vol.11,no.3 :230-238.

Acosta-Nassar M.V., Morell J.M., and Corredor J.E., 1994. The nitrogen budget of a tropical semi-intensive freshwater fish culture pond. J. World Aquacult. Soc. 25, 261-270.

AOAC, 1990. Official Methods of Analysis of the Association of Official, Analytical Chemists, 15th ed. Association of Official Analytical Chemists, Arlington, VA.

APHA, 1985. Standard Methods for the Examination of Water and Wastewater. $16^{\text {th }}$ ed. Washington, D.C. $1268 \mathrm{pp}$.

Avnimelech Y.,1999. Carbon:nitrogen ratio as a control element in aquaculture systems. Aquaculture $176: 227-235$. 
Avnimelech, Y. 2006. Bio-filters: The need for a new comprehensive approach. Aquacultural Engineering, 34, 172- 178.

Beveridge, M. C. M. 1984. Cage and Pen Fish Farming. Carrying Capacity Models and Environmental Impact. FAO Fish. Tech. Paper. (cited in Mongirdas et al., 2017).

Boyd C.E., Corpron K., Bernard E., and Pengseng P., 2006. Estimates of bottom soil and effluent load of phosphorus at a semi-intensive marine shrimp farm. Journal of the World Aquaculture Society, 37:41-47.

Boyd C.E., Tucker C., Mcnevin A., Bostick A. and Clay J., 2007. Indicators of resource use efficiency and environmental performance in fish and crustacean aquaculture. Reviews in Fisheries Science, vol. 15, no. 4, pp. 327360.

Boyd C.E., and Tucker C.S., 1995. Sustainability of channel catfish farming. World Aquaculture, 26:45-53.

Boyd C.E., 1985. Chemical budgets for channel catfish ponds. Trans Am Fish Soc 114: 291-298.

Boyd CE, Wood CW, and Thunjai T., 2002. Aquaculture Pond Bottom Soil Quality Management. Pond Dynmics/ Aquaculture Collaborative Research Support Program. Oregon State University, Corvalis, Oregon, USA, 41.

Boyd CE. 1979. Water quality in warm water fish ponds. Auburn University Agricultural Experiment Station. Craftmaster Printers Inc., Alabama, USA, 359.

Boyd CE., 1995. Bottom Soils, Sediment and Pond Aquaculture. Chapman and Hall, New York, , 348.

Boyd, C.E. and Queiroz, J.F., 2001. Nitrogen, phosphorus loads vary by system, USEPA should consider system variables in setting new effluent rules. Global Aquaculture Advocate, vol. 4, no. 6, pp. 84-86.

Boyd, C.E., 1997. Practical aspects of chemistry in pond aquaculture. Prog. Fish-Cult. 59, 87-93. Brandes, J.A., Devol, A.H., 1997. Isotopic fractionation of oxygen and nitrogen in coastal marine sediments. Geochim. Cosmochim. Acta 61, 1793-1801.

Cho C.Y., Hynes J.D., Wood K.R., and Yoshida H.K., 1991. Quantification of fish culture wastes by biological (nutritional), and chemical (luminological) methods; the development of high nutrient dense (HND) diets. In: Cowey, C.B., Cho, C.Y. (Eds.), Nutritional Strategies and Aquaculture Waste. Proceedings of the First International Symposium on Nutritional Strategies in Management of Aquaculture Waste. University of Guelph, Guelph, Ont., pp. 37-50.

Cripps, S. J., and Bergheim, A. 2000: Solids management and removal for intensive land-based aquaculture production systems. Aquacultural Engineering, 22, 33-56. 
Daniels, H.V., and Boyd, C.E., 1989. Chemical budgets for polyethylene-lined brackishwater ponds. J. World Aquacult. Soc. 20, 53-60.

FAO, 2014 [viewed 22 February 2016]. The state of world fisheries and aquaculture. Rome: FAO. 243 p.

Foy R.H., and Rosell R., 1991. Loadings of nitrogen and phosphorus from a Northern Ireland fish farm. Aquaculture 1991, 96, 17-30.

Funge-Smith S.J., and Briggs M.R.P., 1994. The origins and fate of solids and suspended solids in intensive marine shrimp ponds in Thailand. Summary report from Sonykhla Region of Thailand. Institute of Aquaculture, Stirling, 20.

Gorlach-Lira K., Pacheco C., Carvalho L.C.T., Melo Junior H.N. and Crispm M.C., 2013. The influence of fish culture in floating net cages on microbial indicators of water quality. Brazilian Journal of Biology, 73(3):457-463.

Gross A, and Boyd CE., 1998. A digestion procedure for the simultaneous determination of total nitrogen and total phosphorus in pond water. Journal of the World aquaculture Society; 29(3):300-303.

Hassouna M.M.E., Abd El-Maksoud A.M.S. and Ali A.A.A., 2002. Effect of four commercial diets differing in their crude protein level on Nile tilapia reproductive performance. Egypt J.Aquat. Bio.\&Fish., 6(4) :101-113.

Heinsbroek L.T.N., Thoor R.M.Hv, and Elizondo L.J., 1989. The effect of feeding level on the apparent digestibilities of nutrients and energy of a reference diet for the European eel, Anguilla anguilla L., and the African catfish, Clarias gariepinus (Burchell 1822). In: Abstracts 3rd Int. Symp. Feeding and Nutrition in Fish, 28 August-1 September, 1989, Toba, Japan, pp. 175- 188.

Hopkins J.S., Sandifer P.A., and Browdy C.L., 1994. Sludge management in intensive pond culture and shrimp - effect of management regime on water quality, sludge characteristics, nitrogen extinction, and shrimp production. Aquac. Eng: 13:11-30.

Jamu D.M., and Piedrahita R.H., 2001. Ten-year simulations of organic matter concentrations in tropical aquaculture ponds using the multiple pool modelling approach. Aquacult Eng; 25:187-201.

Kelly L.A., Bergheim A., and Hennessy M.M., 1994. Predicting output of ammonium from fish farms. Water Res., 28: 1403-1405.

Kouba A., Lunda R., Hlavac D., Kuklina I., Hamackova J., Randak T., Kozak P., Koubova A., Buric M., 2018. Vermicomposting of sludge from recirculating aquaculture system using Eisenia andrei: Technological feasibility and quality assessment of end-products. Journal of Cleaner Production 177:665-673 
Lin C. K., Yi Y. and Diana J. S. 1996. The effects of Pond Management Strategies on Nutrient Budgets: Thailand. Fourteenth Annual Technical Report, page 19-24. CRSP.

Lin CK, and Yi Y. 2003. Minimizing environmental impacts of freshwater aquaculture and reuse of pond effluents and mud. Aquaculture; 226:57-68.

Lupatsch, I.,and Kissil, G., 1998. Predicting aquaculture waste from gilthead seabream (Sparus aurata) culture using a nutritional approach. Aquat. Living Resour. 11, 265-268.

Ming-Kui Z, and Li-ping F., 2006. Phosphorus accumulation and eutrophication in feed-supply fresh water fish ponds. Journal of Environmental Sciences, 18:816-821.

Mongirdas V., Žibienė G., and Žibas A., 2017. Waste and its characterization in closed recirculating systems-A review. J. Water Security, 3:1-7.

Muendo P. N., Verdegem M. C. J., Stoorvogel J. J., Milstein A., El-Naggar G., Duc P.M. and Verreth J. A.J. 2014. Sediment Accumulation in Fish Ponds; Its Potential for Agricultural Use. International Journal of Fisheries and Aquatic Studies; 1(5): 228-241.

Muendo PN, Stoorvogel JJ, Gamal NE, and Verdegem MCJ., 2005. Rhizons improved estimation of nutrient losses because of seepage in aquaculture ponds. Aquaculture Research; 36:1333-1336.

Muthuwani, V., and Lin, C.K., 1996. Water Quality and Nutrient Budget in Intensive Shrimp Culture ponds. Proceedings of the World Aquaculture Society Meeting, Bangkok, 1996, p. 270.

Orellana J., Waller U., and Wecker B., 2013. Culture of yellowtail kingfish (Seriola lalandi) in a marine recirculatingaquaculture system (RAS) with artificial seawater. Aquacult. Eng. 2013, 10.1016/j.aquaeng.2013.09.004.

Osti J. A. S., Moraesb M. A. B., Carmob C. F. and Mercante C. T. J., 2018. Nitrogen and phosphorus flux from the production of Nile tilapia through the application of environmental indicators. Brazilian Journal of Biology, 78(1):25-31.

Ozbay G., Blank G., and Thunjai T., 2014. Impacts of Aquaculture on Habitats and Best Management Practices (BMPs). In: Hernandez-Vergara, M. P.; Perez-Rostro, C. I. (Eds). Sustainable Aquaculture Techniques. InTech. http://dx.doi.org/10.5772/57471.

Piedrahita R. H., 2003. Reducing the potential environmental impact of tank aquaculture effluents through intensification and recirculation. Aquaculture, 226, 35-44.

Porter C., Krom M.D., Robbins M.D., Bricknell M.G., and Davidson A., 1987. Ammonia excretion and total $\mathrm{N}$ budget for filthead seabream (Sparus aurata) and its effect on water quality conditions. Aquaculture; 66:287-289. 
Rath KR., 2000. Aquatic environment fresh water aquaculture. Scientific publishers (India), Jodhpur, , 34-71.

Santiago C. B., Aldaba M. B., Abuan E. F., and Laron M. A., 1985. The effects of artificial diets on fry production and growth of Oreochromis niloticus breeders. Aquaculture, 47(2-3), 193-203.

Schneider, O., Amirkolaie, A.K., Vera-Cartas, J., Eding, E.H., Schrama, J.W., and Verreth, J.A.J., 2004. Digestibility, faeces recovery, and related carbon nitrogen and phosphorus balances of five feed ingredients evaluated as fishmeal alternatives in Nile tilapia, Oreochromis niloticus L. Aquac. Res. 35, 1370-1379.

Shrestha, M.K., and C.K. Lin, 1996. Phosphorus fertilization strategy in fish ponds based on sediment phosphorus saturation level. Aquaculture, 142:207219.

Stephens W. W., and Farris J. L., 2004. A biomonitoring approach to aquaculture effluent characterization in channel catfish fingerling production. Aquaculture, 241, 319-330.

Summerfelt S. T. and Vinci, B. J. 2003. Best Waste Management Practices for Recirculating Systems. In: Summerfelt, R. C.; Clayton, R. D. (Eds.). Aquaculture Effluents: Overview of EPA Guidelines and Standards and BMPs for Ponds, Raceways, and Recycle Systems. Publication Office, North Central Regional Aquaculture Center, Iowa State University, Ames, Iowa, 111-133 [online], [cited 21 November 2016].

Summerfelt, S. T.; Binkowski, F. B.; Malison, J. A., and Reinemann, D. J. 2001. Aquacultural wastes and effluents: their characteristics, removal and beneficial uses..

Tavares, S. and Boyd, C. 2003. Comparison of a dry ash method with perchloric acid digestion for total phosphorus analysis of pond sediment. J. Aquaculture in the Tropics, 18: 239-244.

Thoman E.S., Ingall E. D., and Davis D. A., 2001. Arnold C. R. A nitrogen budget for a closed, recirculating mariculture system. Aquacultural Engineering $24195-211$.

Van Der Meer MB, Faber R, Zamora JE, Verdegem MCJ., 1997. Effect of feeding level on feed losses and feed utilization of soya and fish meal diets in Colossoma macropomum (Cuvier). Aquaculture Research 28: 391-403.

Van Rijn, J., 2013. Waste treatment in recirculating aquaculture systems. Aquac. Eng. 53, 49-56.

Wahab M.A., Haque A., Aminul A.K.M., and Bhuiya Z.H., 1984. Nutrient status of bottom soilsof two ponds in BAU (Banglandesh Agricultural University) Campus. Banglandesh Journal of Fisheries, 6:1-10.

Wang X., Olsen L.M., Reitan K.I. and Olsen Y., 2012. Discharge of nutrient wastes from salmon farms: environmental effects, and potential for 
integrated multi-trophic aquaculture. Aquaculture Environment Interactions, 2 (3): 267-283.

Westers H., 1995. Feed and feeding strategies to reduce aquaculture waste. In M. B. Timmons (Ed.). Aquacultural engineering and waste Management. NRAES-90 (pp. 365- 376). Ithaca, New York: Northeast Regional Agricultural Engineering Service.

Wu R.S.S., Lam K.S., MacKay D.W., Lau T.C., and Yam V., 1994. Impact of marine fish farming on water quality and bottom sediment: a case study in the sub-tropical environment. Mar. Environ. Res. 38, 115-145.

Wudtisin I., and Boyd C.E., 2006. Physical and chemical characteristics of sediments in catfish, freshwater prawn, and carp ponds in Thailand. Aquaculture Research, 37:1202-1214.

Zimmo, O.R., van der Steen, N.P., and Gijzen, H.J., 2004. Nitrogen mass balance across pilot-scale algae and duckweed-based wastewater stabilisation ponds. Water Res. 38, 913-920. 
الصور المختلفة للنيتروجين والفففور فى احواض مفرخات اسماك البلطى النيلى

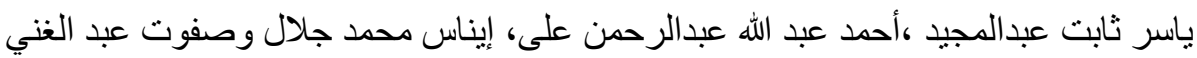
عبد المجيد

المعمل المركزي لبحوث الثروة السمكية، مركز البحوث الزراعية، مصر

\section{الملخص العربي}

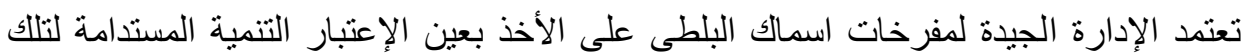

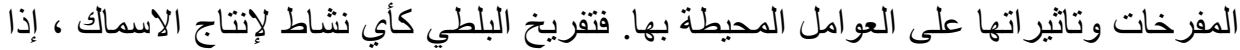

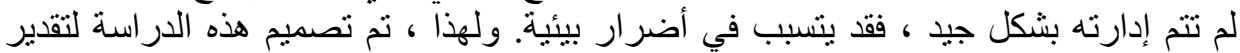

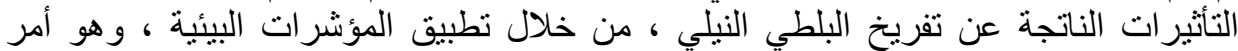

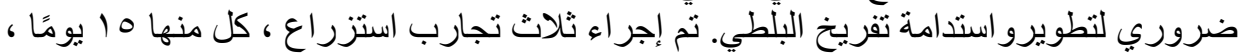

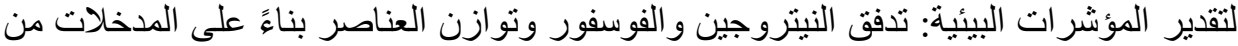

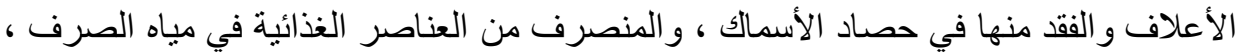

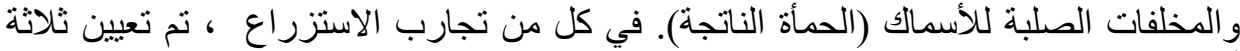

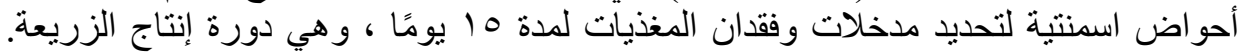

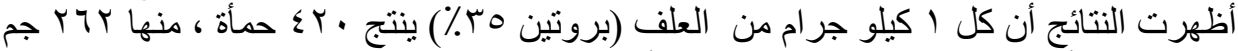

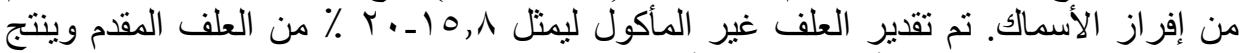

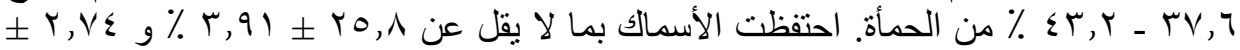

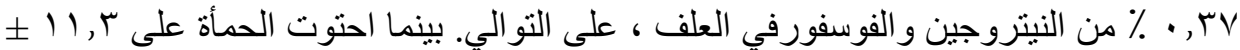

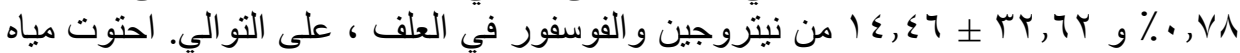

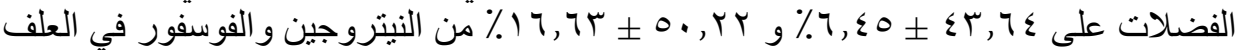

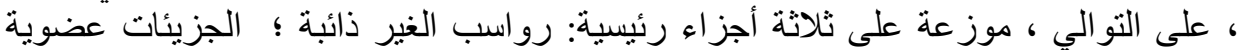

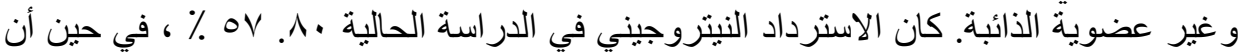

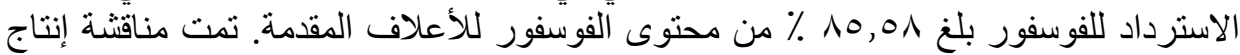

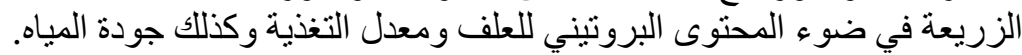

